\title{
THE IMPACT OF HUMAN FREEDOMS ON ECONOMIC GROWTH
}

\author{
Elena Makrevska Disoska \\ Faculty of Economics - Skopje, Ss. Cyril and Methodius University \\ elena.makrevska@eccf.ukim.edu.mk \\ Katerina Shapkova Kocevska \\ Faculty of Law Iustinianus Primus, Ss. Cyril and Methodius University \\ k.shapkova@pf.ukim.edu.mk
}

\begin{abstract}
The impact of formal institutions, including rule of law, human rights, and civil liberties on economic growth has been in the focus of the latest research agenda of the new institutional economics due to the current pandemic of the Corona-19 virus. Some limitations are necessary to be imposed to address a pandemic, but this is a real risk of lasting deterioration in basic human freedoms. Increased surveillance, restrictions on free expression and information, and limits on public participation are becoming increasingly common. The present fear is that the authorities worldwide are using the current situation to repress human rights for political purposes.

This paper aims to explore the effect of the overall institutional environment, understood as the concept of human freedom, on economic prosperity in different jurisdictions around the world.

Human freedom is a general term for personal, civil, and economic freedom and therefore the interconnection with economic growth can be seen in both directions. In our analysis, we use the Human Freedom Index published by the Fraser Institute as a proxy for human freedom. Here, human freedom is understood as the absence of coercive constraint. The index is calculated based on 79 distinct indicators representing different aspects of personal and economic freedom.

This analysis seeks to answer several questions. First, we are interested in examining whether there is empirical evidence about the causality between human freedoms and economic growth. Second, we are interested in whether human freedom has a positive impact on growth rates. And third, we are interested in examining the influence of other determinants on economic growth.

To test the causality between human freedom and economic growth, we have conducted a Granger causality analysis. The empirical strategy for identification of the possible influence of human freedom to growth rates includes the development of ordinary least squares (OLS) panel regression models for selected economies of the world, or around 174 cross-section units (countries) in the period between 2008 and 2017.
\end{abstract}

Key words: Human freedom; Institutions; Economic growth, Pandemic.

JEL classification: $\mathrm{O} 17, \mathrm{O} 43, \mathrm{H} 12$

\section{INTRODUCTION}

The paper seeks to explore the relationship between human freedom and economic growth. Human freedom is a broad term for personal, civil and economic freedom and therefore the interconnection with economic growth can be seen in both directions. Economic growth can impact human rights by reducing economic inequality, effective institutions and governance, investing in human capital and by increasing political stability (Sano and Marslev, 2016). 
Economic development can also have a negative influence by adverse impact on the human rights of workers, citizens, local communities and consumers. However, the inverse relationship is less well understood. The main research question of this paper is whether higher protection of human rights can influence economic development.

Currently, due to the current COVID-19 crisis, the economic slowdown will negatively influence the basic human rights in the following aspects: lack or worsen quality of food, housing, health, education, social protection,increased discrimination and so on(Bohoslavsky, 2020). Other deterioration in basic human rights can be seen in the increased surveillance, restrictions on free expression and information, and limits on public participation. The present fear is that the authorities worldwide are using the current situation to repress human rights for political purposes.

Sectiontwo is the literature review and section threedescribes the data used in our models. In Section fourwe test the direction of causality between GDP per capita and human freedom. Section five describes the methodology used for the creation of the econometric model along with the presentation of the results. The final section concludes.

\section{LITERATURE REVIEW}

There is no academic consensus on the two-way relation between GDP per capita and human freedoms. Koob, Jørgensen and Sano (2017) find no evidence that freedom and participation rights in different regions of the world are harmful to growth: it either promotes growth or has no effect on growth. Blume and Voigt (2007) examine the effect of four different categories of human rights on economic growth and welfare. Precisely, they are interested in the impact of basic human rights, property rights, civil rights and social rights on investment and productivity. Their factor analysis shows that none of these categories of human rights has a significant negative impact on welfare and growth.By using pooled ordinary least squares regression models, the authors have found that basic human rights and property rights encourage investment, while social or emancipatory rights have a distinct impact on productivity development. In general, this group of economists and political scientists take up the stance that protecting human rights collides with economic growth.

Blanton and Blanton (2007) confirm the inverse relationship:economic factors such as trade and investment might act as transmission channels between human rights and economic growth.However, McKay and Vizard (2006) argue that although it is expected that economic development has an impact on human rights, the strength and direction of the relationship are unclear. Other authors (Seymour and Pincus, 2008) warn about the possibility of delegitimization of social choices that deny minority rights to generate growth of the majority in a society. This group of scholars argues that granting too many political or civil rights to individuals could even make the economy worse off.

Nevertheless, a majority of economists emphasize the positive role of human rights on economic prosperity. The fundamental argument in favor of this thesis is that societies, where human rights are respected, generate certainty and predictability for economic actors. Secure and predictable environments are supportive of economic growth and welfare, investments and productivity.

Previous papers of Disoska and Kocevska $(2017$; 2019) werefocusing on the link between institutions and economic growth. The findings were that better and freer institutional quality has a positive influence on economic growth and productivity in the countries from Eastern Europe and also the joint influence of institutional quality and trade increase economic prospects for selected transitional economies from Central and Eastern Europe and the Western Balkans. Therefore, Europe should be oriented towards liberalism and respect all aspects of human freedom to enhance the growth prospects. 


\section{DATA}

We use an unbalanced panel consisted of 174 countries for the period from the year 2008 to 2017. The dependent variable in the model is gross domestic product per capita calculated in 2010 US dollars in constant prices (Variable name: GDP per capita). The variable is obtained from the World Development Indicators from the World Bank. The data are available for the entire period. Logarithmic transformation of this variable is undertaken before using it in the models. All variables are checked for unit roots. We have determined that all variables are stationary at level 0 (appendix 1).

We use several independent variables to explain the volatility in GDP per capita. Our main variable of interest is human freedom. Human freedom is presented by the score of the Human Freedom Index (Vásquez and Porčnik, 2019). This index is a broad measure of human freedom and is calculated by using 76 distinct indicators. These indicators are organized into two broad groups: personal freedom and economic freedom. Personal freedom covers the areas: Rule of Law, Security and Safety, Movement, Religion, Association, Assembly, and Civil Society, Expression and Information, Identity and Relationships. Economic freedom, on the other hand, covers the following topics: Size of Government, Legal System and Property Rights; Access to Sound Money; Freedom to Trade Internationally; Regulation of Credit, Labor, and Business. The index is presented on a scale of 0 to 10 , where 0 stands for least free and 10 represents most free countries and territories. In the latest report (Vásquez and Porčnik, 2019) referring to 2017, total of 162 countries were included. The index is published on a regular, annual base.

Further, we use several economic variables or factors. The first one is Trade. Trade is calculated as the sum of exports and imports of goods and services and is given in the form of a share of gross domestic product. The data is acquired from the World Development Indicators. Thesecond economic factor also obtained from the World Development Indicators database is the unemployment rate (Variable name: Unemployment). Unemployment is understood as a share of the labor force that is without work but available for and seeking employment (definition of labor force and unemployment is distinct for the separate countries). Total factor productivityrefers to the level of the total factor productivity at current PPPs. It is obtained from the Penn World Table 9.1. (Feenstra, Inklaar and Timmer, 2015). The fourth economic variable that we imply in our model is Investment. This variable is given in a form of a ratio of total investment (or gross capital formation) and gross domestic product, both calculated in current local currency.Investment is obtained from the IMF's World Economic Outlook database.

Further, besides human freedom and the economic factors, we introduce two more variables in our models. The first one, Life expectancy,indicates the number of years a newborn infant would live if prevailing patterns of mortality at the time of its birth were to stay the same throughout its life. The data is also published in the World Development Indicators database. We understood life expectancyas a human development variable (UNDP, 2019).

In the end, we introduce one variable that explains the broader political environment. The variable is titled Conflict and is obtained from the Center for Systemic Peace, Major Episodes of Political Violence database. The variable represents the total summed magnitudes of all societal major episodes of political violence (Marshall, 2019).

Descriptive statistics (number of observations, mean, standard deviation, minimum and maximum) are presented in Table 1. The correlation matrix between the variables is given in Table 2. 
Table 1. Descriptive statistics of variables

\begin{tabular}{|l|l|l|l|l|l|}
\hline Variable & Observations & Mean & Std. Dev. & Min & Max \\
\hline GDP per capita & 2230 & 14621.04 & 19900.3 & 214.139 & 111968 \\
\hline Human freedom & 1482 & 6.985904 & 1.058813 & 3.69 & 9.12 \\
\hline Trade & 2148 & 91.82166 & 56.49294 & .167418 & 442.62 \\
\hline Unemployment & 1517 & 8.188234 & 5.924041 & .14 & 37.2499 \\
\hline $\begin{array}{l}\text { Total factor } \\
\text { productivity }\end{array}$ & 1508 & .6444152 & .2585639 & .0986217 & 2.364419 \\
\hline Investment & 2001 & 24.78419 & 8.420553 & -3.744 & 73.002 \\
\hline Life expectancy & 2224 & 70.65124 & 8.929667 & 42.518 & 84.6805 \\
\hline Conflict & 1950 & .4661538 & 1.333406 & 0 & 7 \\
\hline
\end{tabular}

Source: Authors`own calculations

Table 2. Correlation matrix of variables

\begin{tabular}{|c|c|c|c|c|c|c|c|c|}
\hline & $\begin{array}{r}G D P \text { per } \\
\text { capita }\end{array}$ & $\begin{array}{l}\text { Human } \\
\text { freedom }\end{array}$ & Trade & $\begin{array}{r}\text { Investme } \\
n t\end{array}$ & $\begin{array}{r}\text { Life } \\
\text { expectan } \\
c y\end{array}$ & $\begin{array}{l}\text { Unemplo } \\
\text { yment }\end{array}$ & $\begin{array}{r}\text { Total } \\
\text { factor } \\
\text { productiv } \\
\text { ity }\end{array}$ & Conflict \\
\hline $\begin{array}{l}\text { GDP per } \\
\text { capita }\end{array}$ & 1.0000 & & & & & & & \\
\hline $\begin{array}{l}\text { Human } \\
\text { freedom }\end{array}$ & 0.6674 & 1.0000 & & & & & & \\
\hline Trade & 0.3381 & 0.2589 & 1.0000 & & & & & \\
\hline Investment & -0.1643 & -0.2478 & 0.0385 & 1.0000 & & & & \\
\hline $\begin{array}{l}\text { Life } \\
\text { expectancy }\end{array}$ & 0.6369 & 0.6390 & 0.1622 & -0.1634 & 1.0000 & & & \\
\hline $\begin{array}{l}\text { Unemployme } \\
n t\end{array}$ & -0.1389 & -0.0254 & -0.0593 & -0.2517 & -0.1055 & 1.0000 & & \\
\hline $\begin{array}{l}\text { Total factor } \\
\text { productivity }\end{array}$ & 0.6373 & 0.4470 & 0.0147 & -0.1829 & 0.5661 & 0.0347 & 1.0000 & \\
\hline Conflict & -0.1807 & -0.2621 & -0.1799 & -0.0249 & -0.1749 & -0.1138 & -0.0799 & 1.0000 \\
\hline
\end{tabular}

Source:Authors`own calculations

This paper goes further into examining the casual relations between GDP per capita and human freedom index, by performing a Granger causality test and by using the latest data for the Human Freedom Index for 2017 (the report name is 2019). The index is calculated for 162 countries, and we used all the available data to make relevant conclusions for the interdependence between human freedom and economic growth on a global level. Furthermore, in order to quantify the effect of human freedom on economic growth, we use the ordinary least squares (OLS) panel regression model.

\section{CAUSALITY BETWEEN GDPE PER CAPITA AND HUMAN FREEDOM INDEX}

In order to examine the direction of causality between GDP growth and human freedom index, we perform a Granger causality test. We use the latest data for the Human Freedom Index for 2017 (the report name is 2019). The index is a result of the work of the Cato Institute, the Fraser Institute, and the Liberales Institut at the Friedrich Naumann Foundation for freedom and is it free of charge. Another option as to consider human rights as freedom and participation rights defined in Empowerment Rights Index from CIRI human rights data (Cingranelli, and Richards 2008, Koob, Jørgensen and Sano, 2017).

The index is calculated for 162 countries, and we used all the available data to make relevant conclusions for the interdependence between human freedom and economic growth on a global level. 
The Granger causality means that a variable xit is causing yit for each individual if yitis better predicted using all available information instead of using information apart from xit (Granger, 1969). The Granger causality test is performed on the following panel data model:

$$
y i t=\Sigma \gamma k y i, t-k p k=1+\Sigma \beta k x i, t-k r k=0+u i t
$$

The null hypothesis is that there does not exist any causality relations. $H 0: \beta k=0$; the alternative is that there exist lags for which the parameter is nonzero, $H A$ : $\beta k \neq 0$ (Koob, S.A., Skriver, S. and Hans-Otto, J.).The test is performed for the human freedom index (and its sub-indexes) and GDP economic growth - in both directions.

Because we expect that the effect of the human freedom index on economic growth comes with a time lag, the tests are performed with different lag lengths. The data is given in tables with three columns for each separate relationship. The first one summarized the lag lengths (from 1 to 8 ), the second and third columns give the t-statistics and the corresponding pvalue. The null hypothesis is rejected at $99 \%$ significance level. If most of the lags reject the null hypothesis, we conclude that there is long-run relationship between the two observed variables.

Table 3. Causality between GDP per capita and human freedom

\begin{tabular}{|l|l|l|l|l|l|}
\hline \multicolumn{2}{|l|}{$\begin{array}{l}\text { From GDP per capita to human } \\
\text { freedom }\end{array}$} & \multicolumn{4}{|l|}{$\begin{array}{l}\text { From human freedom to GDP } \\
\text { per capita }\end{array}$} \\
\hline Lags & $\begin{array}{l}\text { Test } \\
\text { statistics }\end{array}$ & P-value & Lags & $\begin{array}{l}\text { Test } \\
\text { statistics }\end{array}$ & P-value \\
\hline 2 & 0.53432 & 0.5862 & 2 & $21.4493^{* * *}$ & 7. E-10 \\
\hline 3 & 0.2894 & 0.8333 & 3 & $7.54267^{* * *}$ & 5. E-5 \\
\hline 4 & 0.51536 & 0.7245 & 4 & $3.31973^{* * *}$ & 0.0104 \\
\hline 5 & 0.429290 & 0.8283 & 5 & $3.37431^{* * *}$ & 0.0051 \\
\hline 6 & 1.51178 & 0.1719 & 6 & $3.31781^{* * *}$ & 0.0032 \\
\hline 7 & 1.34722 & 0.2266 & 7 & $2.09092^{* * *}$ & 0.0435 \\
\hline 8 & 0.58661 & 0.7886 & 8 & $3.85264^{* * *}$ & 0.0003 \\
\hline
\end{tabular}

Note: The model is estimated using Granger causality stacked test (common coefficients). Lags refer to the number of lags of the regressor, the test statistic is F-stat and is reported with corresponding p-values. ${ }^{*} \mathrm{p}<0.10$, $* * \mathrm{p}<0.05, * * * \mathrm{p}<0.01$

In the first three columns is presented the relationship of GDP per capita (constant 2010 US\$), as a measure of economic growth on the human freedom index. According to the pvalue, we accept the null hypothesis, meaning that economic growth does not affect human freedom. The inverse relationship i.e. the effect of human freedom on GDP per capita is positive and statistically significant according to the performed Granger causality test.

\section{ECONOMETRIC MODEL, RESULTS AND DISCUSSION}

In order to confirm the relationship between human freedom and GDP growth, we extend the model by adding instrumental variables and the use of the OLS model in a panel data framework. The form of panel data regression equation is similar to ordinary least square, i.e: Description: For $\mathrm{i}=1,2, \ldots ., \mathrm{N}$ and $\mathrm{t}=1,2, \ldots ., \mathrm{T}$. Where $\mathrm{N}=$ Number of individuals or cross section and $\mathrm{T}$ is the number of time periods. From this model NxT can be generated 
equation,that is equal to $\mathrm{T}$ equation of cross and as much $\mathrm{N}$ equation coherent time or time series.

$$
y i t=\alpha+\beta^{\prime} k \times x+u i t \text { where } t=1, \ldots, \text { Tare years and } i=1, \ldots, N \text { are countries. }
$$

$y i t$ is the dependent variable, GDP growth per capita, $x i$, are the explanatory variables, the Human freedom Rights index, and also other intermediary factors through which freedom and participation rights may affect growth such as economic and institutional factors. uit is the unobserved error term. We used pooled regression, based on Hausman test and F-test of individual effects.

The dependant variable in the models is GDP per capita, measured in constant 2010 international dollars which is a variable in real terms. The variable is not used in absolute terms, but as a logarithm of the value. Different independent variables are employed to explain the variance of the dependent variable. Independent variables are used in linear form. Therefore, we constructed several models by adding an extra variable in each model. All of the constructed models are panel regressions using the OLS method.

We were working with unbalanced panel database since some of the data were missing. However, countries with very limited data have been discarded. Another methodological obstacle for the research was to find adequate variable that would quantify and measure human rights. Of course the Human freedom index is a broad measure of human rights, so we were not able to indicate which of the components have higher influence on the economic growth. Also, considerable variations among countries cannot be determined. Despite these methodological challenges, we are giving the following explanation of the model in the following Table.

Table 4. Regression models (Dependent variable: logGDP per capita in constant 2010 \$US)

\begin{tabular}{|c|c|c|c|c|c|c|}
\hline & (1) & (2) & (3) & (4) & (5) & (6) \\
\hline $\begin{array}{l}\text { Human } \\
\text { freedom }\end{array}$ & $\begin{array}{l}1.0136 \\
(0.0276) \\
* * *\end{array}$ & $\begin{array}{l}0.9625 \\
(0.2970)^{* * *}\end{array}$ & $\begin{array}{l}0.370 \\
(0.0304)^{* * *}\end{array}$ & $\begin{array}{l}0.3433 \\
(0.0300)^{* * *}\end{array}$ & $\begin{array}{l}0.2568 \\
(0.0257)^{* * *}\end{array}$ & $\begin{array}{l}0.3995 \\
(0.0351)^{* * *}\end{array}$ \\
\hline Trade & & $\begin{array}{l}0.0031 \\
(0.0005)^{* * *}\end{array}$ & $\begin{array}{l}0.0021 \\
(0.0004)^{* * *}\end{array}$ & $\begin{array}{l}0.0022 \\
(0.0004)^{* *}\end{array}$ & $\begin{array}{l}0.0019 \\
(0.0003)^{* * *}\end{array}$ & $\begin{array}{l}0.0022 \\
(0.0004) * * *\end{array}$ \\
\hline Investment & & & $\begin{array}{l}0.0080 \\
(0.0027)^{* * *}\end{array}$ & $0.0069 * * *$ & & \\
\hline $\begin{array}{l}\text { Life } \\
\text { expectancy }\end{array}$ & & & $\begin{array}{l}0.1062 \\
(0.0034)^{* * *}\end{array}$ & $\begin{array}{l}0.107 \\
(0.0033)^{* * *}\end{array}$ & $\begin{array}{l}0.0675 \\
(0.0032) * * *\end{array}$ & $\begin{array}{l}0.0656 \\
(0.0032) * * *\end{array}$ \\
\hline Unemployment & & & & $\begin{array}{l}-0.0296 \\
(0.0038)^{* * *}\end{array}$ & $\begin{array}{l}-0.0183 \\
(0.0034)^{* * *}\end{array}$ & $\begin{array}{l}-0.0208 \\
(0.0035)^{* * *}\end{array}$ \\
\hline $\begin{array}{l}\text { Total factor } \\
\text { productivity }\end{array}$ & & & & & $\begin{array}{l}2.6716 \\
(0.1094)^{* * *}\end{array}$ & $\begin{array}{l}2.5169 \\
(0.1119)^{* * *}\end{array}$ \\
\hline Conflict & & & & & & $\begin{array}{l}-0.0286 \\
(0.0049)^{* * *}\end{array}$ \\
\hline R-squared & 0.4799 & 0.4913 & 0.7173 & 0.7292 & 0.8326 & 0.8361 \\
\hline $\begin{array}{l}\text { Adjusted R- } \\
\text { squared }\end{array}$ & 0.4795 & 0.4905 & 0.7165 & 0.7282 & 0.8318 & 0.8351 \\
\hline F-statistics & $1353.617 * * *$ & $688.9605^{* * *}$ & $864.6189 * * *$ & $730.8067 * * *$ & $1074.273^{* * *}$ & $883.4178^{* * *}$ \\
\hline
\end{tabular}

Note: Standard errors are given in parenthesis.

p-value: *** significant at 99\% level; ** significant at $95 \%$ level, * significant at $90 \%$ level. 
The results from the regressions are presented in the previous table. All models have high $\mathrm{R}$ squared which explains the variability of the dependent variables the most of the variability of the independent variable. Also, the R squares are increasing meaning that each additional variable has additional influence on the dependant variable. The F-statistics is also reported. It indicates the significance level of influence of predictor variable to response variables. All regressions show high statistical significance (at 99\% level).

The first model, the model (1), is a simple regression where human freedom is an independent variable. The estimated value of the coefficient is 1.01. On average, if human freedom increases by 1 unit on a $0-10$ scale, GDP per capita is expected to increase by 10,1 percentages.Compared with the other indicators, the value of the coefficient is significantly higher. That just confirms the main hypothesis of the paper, that there is a strong positive relationship between human freedom and economic prosperity.

The following models (2-6) are improved by including additional variables as independent variables. The independent variables are economic variables as possible explanatory variables of GDP per capita, according to the academic literature. We can conclude that adding new variables in the model slightly improves the explanatory power of the regressions, presented by higher values of adjusted coefficient of determination. Most of the estimates are significant at 99 percent level.

The variable human freedom has permanently statistical and economical significance. Trade, as well, is statistical and economical significant independent variable, with coefficients ranging from 0.0019 to 0.0031 . Investment proves to have a positive influence on the GDP per capita, or in other words, one percentage change in the investment (measured as \% of GDP) will increase in GDP per capita by $0.69-0.8 \%$. The empirical literature confirms the positive correlation between these two variables.

Life expectancy has a positive and strong correlation with GDP per capita in the observed countries all around the world, ceteris paribus. Therefore, all else held constant increase in the averagenumber of years of the humans by one year will increase GDP per capita by 6.5 percent -10.6 percentage, on average. The results are both statistically and economically significant. Regarding the variable unemployment, we use the data from the national statistics and the indicator is expressed as a percentage of the total labor force. The estimated coefficient confirms the negative relationship with the GDP per capita, meaning that an increase in the unemployment rate by 1 unit will decrease the GDP per capita by $1.8 \%$ to $3 \%$. Another economic variable is the total factor productivity. The difference in total factor productivity explains the variations in income between countries. In this model, the total factor productivity have the highest coefficient ranging from 2.51 to 2.67.

Aside from economic variables we include one political variable: Conflict.This variable represents the total summed magnitudes of all societal major episodes of political violence and conflict regions. The variable is re-scaled from $0-100$. On average, 1 unit increase in indicator for political violence and conflict regions, in the sample countries, leads to 2.86 percentage negative changes in GDP per capita, ceteris paribus.

\section{CONCLUSION}

The relationship between human development and economic growth is in two directions. The improvements in human development lead to higher economic growth, which further promotes human development.In this paper, we developed ordinary least squares (OLS) panel regression models for countries all around the world, in the period between 2008 and 2017 to quantify the effect of human freedom on economic growth. We included a number of economic variables in the model. The cross-country regression models demonstrate that human freedom, life expectancy and total factor productivity have the highest influence and are statistically significant determinants of economic growth. 
The results from the econometric model can be used as a policy recommendation in the current situation of pandemics. Therefore, if governments are imposing a disproportionate restriction that limits the information, free expression in the name of stopping Covid-19, the negative effects will extend far beyond this outbreak. People will suffer a lasting deterioration in basic freedoms, and they will lose confidence in the institutions. The challenge of the policy makers is finding an appropriate balance between protecting public health and minimizing economic consequences.

\section{References:}

Bohoslavsky, J.P. (2020).COVID-19: Urgent appeal for a human rights response to the economic recession, United Nations Human Rights, Geneva.

Blume, Lorenz, and Voigt,Stefan. (2007). "The economic effects of human rights." Kyklos 60, 4: 509-538.

Blanton, S. L., and Blanton, R. G. (2007). What attracts foreign investors? An examination of human rights and foreign direct investment. The Journal of Politics, 69(1), 143-155.

Granger, C. W. J. (1969). "Investigating Causal Relations by Econometric Models and Crossspectral Methods". Econometrica, 37, 424-438.

Feenstra, Robert C., Robert Inklaar and Marcel P. Timmer (2015). "The Next Generation of the Penn World Table" American Economic Review, 105(10), 3150-3182.

International Monetary Fund. (2019). World Economic Outlook: Global Manufacturing Downturn, Rising Trade Barriers. Washington, DC, October.

Koob, S.A., Jorgensen, S.S. and Sano, H.O (2017): Human Rights and economic growth: an econometric analysis of freedom and participation rights. The Danish Institute for Human Rights, Copenhagen.

Koob, S.A., Skriver, S.J. and Sano, H.O. (2017): Human Rights and Economic Growth: An Econometric Analysis of Freedom and Participation Rights, The Danish Institute for Human Rights, Copenhagen.

Marshall, M.G., Center for Systemic Peace (July 25, 2019). Major episodes of Political violence (MEPV) and conflict regions, 1946-2018.

Marslev, K., and Sano, H. O. (2016). The Economy of Human Rights: Exploring Potential Linakages between Human Rights and Economic Development. Matters of Concern.

McKay, A., and Vizard, P. (2006). Rights and economic growth: Inevitable conflict or 'common ground'?. Human Rights and Poverty Reduction: Realities, Controversies and Strategies, 41.

Makrevska Disoska. E. and Shapkova Kocevska, K. (2019). "Human Freedom and Economic Prosperity: Evidence from Eastern Europe." Visio Journal (4).

Seymour, D., and Pincus, J. (2008). Human rights and economics: The conceptual basis for their complementarity. Development Policy Review, 26(4), 387-405.

Shapkova Kocevska, K., and Makrevska Disoska, E. (2017). Inuence of Trade and Institutions on Economic Growth in Transitional Economies: Evidences from Countries from Central and Eastern Europe and Western Balkans. Economic Analysis.

United Nations Population Division. World Population Prospects: 2019 Revision.

Vásquez, I.,and Porčnik, T. (2019). The Human Freedom Index 2019: A Global Measurement of Personal, Civil, and Economic Freedom. Washington: Cato Institute, Fraser Institute, and the Friedrich Naumann Foundation for Freedom.

World Bank national accounts data, and OECD National Accounts data files. 
Appendix 1. Unit root tests

\begin{tabular}{|l|r|r|r|r|}
\hline \multicolumn{4}{|c|}{ INDIVIDUAL INTERCEPT } & \multicolumn{2}{c|}{ INTERCEPT AND TREND } \\
\hline & $\begin{array}{l}\text { ADF - Fisher } \\
\text { Chi-square }\end{array}$ & $\begin{array}{l}\text { PP - Fisher } \\
\text { Chi-square }\end{array}$ & $\begin{array}{l}\text { ADF - Fisher } \\
\text { Chi-square }\end{array}$ & $\begin{array}{l}\text { PP - Fisher Chi- } \\
\text { square }\end{array}$ \\
\hline Log (GDP per capita) & $441.415 * * *$ & $621.987 * * *$ & 298.502 & $512.842 * * *$ \\
\hline Human freedom & 323.531 & $400.482 * * *$ & 287.537 & $466.182 * * *$ \\
\hline Trade & 366.951 & $391.847 * *$ & 367.235 & $562.185 * * *$ \\
\hline Investments & $388.687 * * *$ & $433.026 * * *$ & 321.54 & $431.501 * * *$ \\
\hline Life expectancy & $1252.36 * * *$ & $1126.48^{* * *}$ & $550.657 * *$ & $542.391 * * *$ \\
\hline Unemployment & $297.538^{* * *}$ & $346.408^{* * *}$ & 196.375 & $293.379 *$ \\
\hline $\begin{array}{l}\text { Total factor } \\
\text { productivity }\end{array}$ & $273.725 * *$ & $322.244 * * *$ & 201.008 & $288.189 * * *$ \\
\hline Conflict & $66.6749 *$ & $69.2154 * *$ & $70.483 *$ & $87.555 * * *$ \\
\hline
\end{tabular}

Note: p-value: $* * *$ significant at $99 \%$ level; $* *$ significant at $95 \%$ level, * significant at $90 \%$ level. 